\title{
Antidiabetic and hypolipidemic potential of Campomanesia xanthocarpa seed extract obtained by supercritical $\mathrm{CO}_{2}$
}

\author{
A. Regginato ${ }^{a}$ (D), L. Cunico ${ }^{b}$ (D), K.T. Bertoncello ${ }^{b}$ (D), M. S. Z. Schindler ${ }^{a}$ (D), R. Chitolina CD, $^{\text {(D) }}$

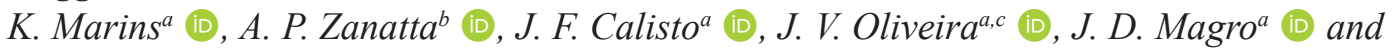 \\ L. Zanatta ${ }^{a, b, d *}$
}

aUniversidade Comunitária da Região de Chapecó - UNOCHAPECÓ, Programa de Pós-graduação em Ciências Ambientais, Chapecó, SC, Brasil

bUniversidade Comunitária da Região de Chapecó - UNOCHAPECÓ, Curso de Graduação em Farmácia, Chapecó, SC, Brasil

'Universidade Federal de Santa Catarina - UFSC, Centro Tecnológico, Departamento de Engenharia Química e Engenharia de Alimentos, Florianópolis, SC, Brasil

dUniversidade do Estado de Santa Catarina - UDESC, Centro de Educação Superior do Oeste, Departamento de Enfermagem, Chapecó, SC, Brasil

*e-mail: leila.zanatta@gmail.com; leila.zanatta@unochapeco.edu.br

Received: August 13, 2019 - Accepted: February 18, 2020 - Distributed: August 31, 2021

(With 5 figures)

\begin{abstract}
Campomanesia xanthocarpa, a plant belonging to the Myrtaceae family, is popularly known as gabiroba. Leaves of gabiroba has been popularly used to treat various diseases, including inflammatory, renal, and digestive, among others. Additionally, studies have shown an effect to reduce blood cholesterol levels. The aim of this study was to evaluate the antihyperglycemic and hypolipidemic effects of Campomanesia xanthocarpa seed extract in hyperglycemic rats. The results showed that $400 \mathrm{mg} / \mathrm{kg}$ of seed extract was able to decrease blood glucose levels and to increase the muscular and hepatic glycogen content as well as to inhibit the sucrase and maltase activity. At doses of $200 \mathrm{mg} / \mathrm{kg}$ and $800 \mathrm{mg} / \mathrm{kg}$, the activity of these enzymes was also reduced. In the lipid profile $400 \mathrm{mg} / \mathrm{kg}$ produced a decrease in total and LDL cholesterol serum levels; and with $200 \mathrm{mg} / \mathrm{kg}$ there was an increase in HDL cholesterol levels. The extract did not present hepatic and renal toxic effects at the different doses tested. The results suggest that the treatment with Campomanesia xanthocarpa seeds extract is useful in reducing glycemia, total cholesterol and LDL levels with potential adjuvant therapeutic in the treatment of diabetes and hypercholesterolemia, however, additional pharmacological and toxicological studies are still required.
\end{abstract}

Keywords: Diabetes mellitus, Campomanesia xanthocarpa, hypolipidemic effect.

\section{Potencial Antidiabético e hipolipidêmico do extrato das sementes de Campomanesia xanthocarpa obtido por $\mathrm{CO}_{2}$ supercrítico}

\section{Resumo}

Campomanesia xanthocarpa, planta pertencente à família Mirtaceae, é popularmente conhecida como gabiroba. Folhas da gabiroba são popularmente usadas para tratar de doenças inflamatórias, renais, digestivas entre outras. Além disso, estudos têm mostrado um efeito redutor dos níveis de colesterol. O objetivo deste estudo foi avaliar os efeitos anti-hiperglicêmico e hipolipidêmico do extrato de sementes de Campomanesia xanthocarpa em ratos hiperglicêmicos. Os resultados mostraram que $400 \mathrm{mg} / \mathrm{kg}$ do extrato da semente foi capaz de reduzir os níveis de glicose sanguínea e aumentar o conteúdo de glicogênio hepático e muscular, bem como inibir a atividade da maltase e sacarase. Na dose de $200 \mathrm{mg} / \mathrm{kg}$ e $800 \mathrm{mg} / \mathrm{kg}$, a atividade das enzimas também foi reduzida. No perfil lipídico, $400 \mathrm{mg} / \mathrm{kg}$ produziu uma redução nos níveis séricos de colesterol total e LDL e com $200 \mathrm{mg} / \mathrm{kg}$ houve um aumento nos níveis de colesterol HDL. O extrato não apresentou efeitos tóxicos hepáticos e renais nas doses testadas. Os resultados sugerem que o tratamento com o extrato de Campomanesia xanthocarpa é eficaz na redução da glicemia, de colesterol total e LDL com potencial para tratamento adjuvante do diabetes e hipercolesterolemia, no entanto estudos farmacológicos e toxicológicos adicionais são necessários.

Palavras-chave: Diabetes mellitus, Campomanesia xanthocarpa, efeito hipolipidêmico. 


\section{Introduction}

Diabetes mellitus (DM) is a serious global health problem affecting about 425 million people worldwide (WHO, 2018). DM is a chronic disease characterized by an elevated blood sugar level (hyperglycemia) which is due to carbohydrate, protein, and lipid metabolism disturbance caused by an absolute or relative deficiency of insulin or by insulin resistance at the cellular level (WHO, 2018). It is well established that hyperglycemia and diabetic dyslipidemia associated lead to several comorbidities including macro- and microvascular damage (Naveen and Baskaran, 2018). For a significant number of patients, the treatment of Type 2 DM (T2DM) must include pharmacological agents in order to reach satisfactory glycemic control as well as multifactorial risk reduction (Khavandi et al., 2017). In this context, many synthetic drugs have been widely used for the treatment of diabetes and dyslipidemia, but herbal medicines still remain a popular choice. In addition, the use of plant-derived drugs for diabetes has been approved by the World Health Organization (WHO, 2002).

Campomanesia xanthocarpa Berg. (Myrtaceae), popularly known as guavirova or guabirobeira is found in the south of Brazil, Argentina, Paraguay and Uruguay (Lorenzi, 2008). Popularly it is used for inflammatory, urinary, and rheumatic diseases, and hypercholesterolemia (Alice et al., 1995). In addition, studies have proven the plant possesses a wide spectrum of therapeutic effects among them the antiulcerogenic (Markman et al., 2004) inflammatory (Viecili et al., 2014), antidiarrheal and antimicrobial activity (Souza-Moreira et al., 2011). Beside these, the antiplatelet, antithrombotic, fibrinolytic (Klafke et al., 2012; Otero et al., 2017) antioxidant (Viecili et al., 2014) and hypotensive potential (Sant'Anna et al., 2017).

Among the compounds found in the leaves (Pereira et al., 2012) and fruits (Sant'Anna et al., 2017) of the plant are the phenolic compounds (gallic acid, chlorogenic acid and quercetin) while the seeds are rich in terpenoids, flavonoids and alkaloids (Capeletto et al., 2016). Flavonoids and triterpenes are secondary metabolites present in several plant species in variable amount and possess various therapeutic properties described, among them the antidiabetic (Alkhalidy et al., 2018; Hussain et al., 2017; Leonidas et al., 2017). Conventionally, natural compounds have been extracted from plant materials by using different solvents, but these procedures result in contaminating the target compounds/extracts with extraction solvents (Brglez Mojzer et al., 2016).

Supercritical fluid extraction (SFE) is an alternative method considered as a technological innovation because it uses supercritical fluids as solvents and its use in industrial processes is increasing due to the environmental and quality factors involved (Silva et al., 2016a; Paula et al., 2016). It is a process free of toxic waste, which does not cause the thermal degradation of the extracts and active principles. There is a wide range of compounds that can be used as supercritical fluids. From the environmental point of view, the most widely used is carbon dioxide due to its characteristics, such as being non-toxic, non-reactive, environmentally acceptable and non-flammable, which makes it a very attractive solvent for the preparation of extracts and oils with pharmaceutical application (Knez et al., 2014; Rodríguez-Pérez et al., 2016)

Considering the relevance of C.xanthocarpa extracts to treat several diceases, especially T2DM (Tangvarasittichai, 2015), this study aimed at evaluating the hypoglycemic and hypolipidemic effects in rodents of C. xanthocarpa seed extracts obtained from SFE- $\mathrm{CO}_{2}$ fluid technique.

\section{Material and Methods}

\subsection{Plant material and extract production}

The fruits of Campomanesia xanthocarpa Berg were collected from native plants at Quilombo city, Southern Brazil (2647'23.6”'S, 52 $\left.45^{\circ} 42.41^{\prime \prime} \mathrm{W}\right)$. The voucher specimen was identified and deposited in the Herbarium at Universidade Comunitária de Chapecó (Herbarium Unochapecó, SC, Brazil) under the access number 3153. The extraction from the seeds was carried out by supercritical extraction technique according to Capeletto (2015). Approximately $30 \mathrm{~g}$ of the dried and ground seeds were placed into extraction compartment of the apparatus. $\mathrm{CO}_{2}$ was pumped at a constant flow rate $(2 \mathrm{~mL} / \mathrm{min})$ and kept in contact with the seeds for at least 30 minutes to stabilize the system. Extraction took place for 150 minutes at $40{ }^{\circ} \mathrm{C}$ and 250 bar of pressure. After that, the extract was collected and the amount obtained was weighed. This procedure was performed until no further changes in the weight of the extract were observed (Capeletto et al., 2016). The extract was then stored at $-20{ }^{\circ} \mathrm{C}$ for further use in the biological assays.

\subsection{Chemical characterization of the extract}

The extract was analyzed by Agilent GC/MS (7890B) gas chromatography coupled to a quadripolar mass spectrometer (5977A) (Agilent Technologies, Palo Alto, CA, USA). The experimental conditions of the GC/MS system were described by (Scapinello et al., 2018) with some adjustments. Briefly, the system conditions were as follows: Agilent 19091S capillary column, dimension: $30 \mathrm{~m} \times 250 \mu \mathrm{m} \times 0.25 \mu \mathrm{m}$. The mobile phase flow (carrier gas: $\mathrm{He}$ ) was adjusted to $1.0 \mathrm{~mL} \mathrm{~min}^{-1}$. The GC temperature program was $40.0^{\circ} \mathrm{C}$ at $4.0 \mathrm{~min}$ to $240.0^{\circ} \mathrm{C}$ at a rate of $10{ }^{\circ} \mathrm{C} \mathrm{min}{ }^{-1}$ and up to $300.0{ }^{\circ} \mathrm{C}$ at a rate of $40.0^{\circ} \mathrm{C} \mathrm{min}^{-1}$ (maintained for $5 \mathrm{~min}$ ). The injector temperature was $280.0{ }^{\circ} \mathrm{C}$, sample injection volume $1 \mu \mathrm{L}$, split ratio $1: 20$, the extract was solubilized in dichloromethane $10 \mathrm{mg} \mathrm{ml}^{-1}$. The MS transferline temperature was set to $150.0{ }^{\circ} \mathrm{C}$ and the source of ions temperature was set at $230.0^{\circ} \mathrm{C}$. For GC-MS detection, an electron ionization system was used with ionization energy set at $70 \mathrm{eV}$, and mass range $\mathrm{atm} / \mathrm{z} 40-400$. The chemical components present in the extracts were identified by comparison with the equipment library (Agilent P/N G1033A). The relative amounts of each individual component were calculated using their respective peak areas in the chromatogram. 


\subsection{Experimental animals}

The International Guidelines for Care and Use of Laboratory Animals were followed for all experiments, and the experimental protocol was approved by the local Ethics Committee on Animal Use (CEUA-Unochapeco Number 006/2016). Male Wistar rats weighing 160-200 g (50-55 day-old) from the Central Animal House-Unochapecó were used. They were housed in plastic cages and fed on pellets $\left(\right.$ Biobase - Biotec $^{\mathcal{C}}$ ) with free access to tap water. Room temperature was controlled at $22 \pm 2{ }^{\circ} \mathrm{C}$ with a $12 \mathrm{~h}$ light:12 h dark cycle (lights on at 07:00 am and off at 07:00 pm) and minimal noise. Animals described as fasted were deprived of food for $12 \mathrm{~h}$ but it had free access to water.

\subsection{Studies of Campomanesia xanthocarpa seeds extract on the oral glucose tolerance curve}

Rats were divided into groups of six animals. Group I: normal rats that received $1 \%$ tween 80 solution in saline $(0.5 \mathrm{~mL} / 100 \mathrm{~g} \mathrm{bw})$; Group II: hyperglycemic rats that received glucose solution ( $4 \mathrm{~g} / \mathrm{kg} ; 8.9 \mathrm{M})$; Group III, IV and V: hyperglycemic rats that received glucose solution plus Campomanesia xanthocarpa seeds extract solution (200, 400 or $800 \mathrm{mg} / \mathrm{kg}$, respectively) (Zanatta et al., 2008) and Group VI: hyperglycemic rats treated with glibenclamide $(10 \mathrm{mg} / \mathrm{kg})+$ glucose solution, by gavage. Glucose $(4 \mathrm{~g} / \mathrm{kg})$ was administrated $30 \mathrm{~min}$ after the rats received the treatment (zero time) (Frederico et al., 2012). Blood samples from the tail vein were collected just before (zero time), and at 60,90 and $210 \mathrm{~min}$ after treatment and the serum glucose levels $(\mathrm{mg} / \mathrm{dL})$ were assayed by a glucometer (Accu-Chek ${ }^{\circledR}$ Performa) (Nicolau et al., 2009). At the end of the experimental period, the animals were anesthetized by a mixture of lidocaine and sodium thiopental (10 and $150 \mathrm{mg} / \mathrm{kg}$, respectively). Blood aliquots were collected by cardiac puncture for biochemical analyses, and the animals were then euthanized by exsanguination (CONCEA, 2013). Liver and soleus muscle were collected, weighed, and immediately homogenized for the evaluation of glycogen content. A segment of the small intestine was removed for disaccharidases activity assay.

\subsection{Glycogen content measurements}

Glycogen was isolated from the rat liver and soleus muscle, and measured after 210 min of treatment as described by Krisman with minor modifications (Zanatta et al., 2008).

\subsection{Disaccharidases isolation and assay}

A segment of the small intestine was removed, washed, dried, weighed, trimmed and homogenized with $0.9 \% \mathrm{NaCl}$. The resulting extract was centrifuged $(8,000 \mathrm{rpm} / 8 \mathrm{~min})$ (Pereira et al., 2012). Maltase (EC 3.2.1.20), lactase (EC 3.2.1.23) and sucrase (EC 3.2.1.48) activities were determined using a glucose diagnosis kit based on the reagent glucose oxidase. For determination of the disaccharidase activity $10 \mu \mathrm{l}$ of supernatant were incubated at $37^{\circ} \mathrm{C}$ for $60 \mathrm{~min}$ with $10 \mu \mathrm{l}$ of the substrate (Dahlqvist, 1984). One enzyme unit (U) was defined as the amount of enzyme that catalyzed the release of $1 \mu \mathrm{mol}$ of glucose per min under the assay conditions. The specific activity was defined as enzyme activity (U) per mg of protein. Protein was determined according to method previously described by Peterson (1979)

\subsection{Biochemical analysis of blood samples}

Serum total cholesterol (TC), LDL, HDL, triglycerides (TG), creatinine and aspartate aminotransferase (AST) levels were determined by enzymatic colorimetric methods (UV/Vis) using commercial Labtest ${ }^{\circledR}$ kits according to the manufacturer's instructions.

\subsection{Insulin serum measurement}

The plasma insulin levels were measured by ELISA according to the manufacture's instructions. Insulin levels were estimated by means of colorimetric measurements at 450 and $550 \mathrm{~nm}$ through interpolation from a standard curve. Samples were analysed in duplicate and results were expressed as ng insulin/ml serum (Castro et al., 2018). The sensitivity of the assay was $5 \mu \mathrm{UI} / \mathrm{mL}$.

\subsection{Statistical analysis}

The results are means \pm SEM. One-way or two-way analysis of variance (ANOVA) followed by Bonferroni post hoc test were used to identify significant differences between groups. Differences were considered significant at $p \leq 0.05$.

\section{Results and Discussion}

\subsection{Chemical constituents of Campomanesia xanthocarpa seeds extract}

The critical $\mathrm{CO}_{2}$ pressure is 73.8 bar at $31.1{ }^{\circ} \mathrm{C}$, which is relatively easy to achieve and allows for industrial scale use without much energy expenditure (Ruttarattanamongkol et al., 2014). The pressure used in this experiment was 250 bar (density $879 \mathrm{~kg} / \mathrm{m}^{3}$ ). The polarity of the supercritical $\mathrm{CO}_{2}$ in these conditions is similar to that of hexane or others non polar solvents commonly used in extraction processes with the advantage of being easily separated from the extract without changing its chemical composition (Shi et al., 2018). Thus, low polarity causes that mainly apolar compounds such as terpenes, fatty acids and carotenoids are extracted. Table 1 shows the compounds identified by chromatographic analysis. Among them it can be highlighted the higher concentration of caryophyllene (11.80\%), $\alpha$-Eudesmol (11.64\%), Guaiol (9.52\%), $\alpha$-Selinene $(9.20 \%)$ and $\beta$-cadinene $(7.87 \%)$.

The presence of a variety of compounds in the extract as well as the synergy between them may have been responsible for the biochemical results verified in this work. Natural products represent a source of biologically active molecules that have several important physiological, preventive and curative roles. The $\alpha$-Eudesmol, one of the major compounds of $C$. xanthocarpa extract, is a sesquiterpene known to reduce cell proliferation and to induce tumour cell death (Bomfim et al., 2013) besides the anti-neurogenic inflammation action (Asakura et al., 2000). 
Table 1. Chemical composition of C. xanthocarpa seed extract produced by supercritical $\mathrm{CO}_{2}$ tecnique.

\begin{tabular}{clcc}
\hline Peak & \multicolumn{1}{c}{ Compound } & Retention time (min) & \% of compound \\
\hline 1 & $\alpha$-Copaene & 11.413 & 2.25 \\
2 & Caryophyllene & 11.639 & 11.8 \\
3 & Alloaromadendrene & 11.678 & 1.55 \\
4 & Humulene & 11.999 & 4.44 \\
5 & y-Muurolene & 12.109 & 4.16 \\
6 & $\beta$-Selinene & 12.271 & 6.51 \\
7 & $\alpha$-Selinene & 12.399 & 9.20 \\
8 & y-Cadinene & 12.464 & 2.66 \\
9 & $\beta$-Cadinene & 12.555 & 7.87 \\
10 & Spathulenol & 12.684 & 3.95 \\
11 & Caryophyllene oxide & 12.751 & 2.07 \\
12 & Guaiol & 12.882 & 9.52 \\
13 & y-Eudesmol & 12.937 & 3.20 \\
14 & $\alpha$-Epi-cadinol & 13.029 & 2.30 \\
15 & $\alpha$-Eudesmol & 13.069 & 11.64 \\
16 & Bulnesol & 13.438 & 6.80 \\
17 & Pinostrobinchalcone & 13.496 & 1.53 \\
18 & 5,7 Dimethoxyflavone & 13.564 & 0.84 \\
Total & & & 92.29
\end{tabular}

Similarly, guaiol has been shown to have good action as a promising drug against Leishmania amazonenses (Garcia et al., 2018) and for antitumor treatment in lung neoplasms (Yang et al., 2016). Caryophyllene is a natural sesquiterpene that presents a wide range of biological activities, including anesthetic, antioxidant, anti-inflammatory, anticancer and anti-diabetic actions (Pant et al., 2014; Basha and Sankaranarayanan, 2014). Others have also reported that sesquiterpenes and other terpenoids have an anti-diabetic potential by stimulating insulin secretion and glucose uptake, improving glycogen synthesis and inhibiting $\alpha$-glucosidase (Zhao et al., 2012; Naveen and Baskaran, 2018). In this context, the effects observed with $C$. xanthocarpa may be due to the presence of sesquiterpenes such as caryophyllene.

\subsection{Effect of Campomanesia xanthocarpa seeds extract on oral glucose tolerance curve and insulin secretion}

The effects of different doses of the extract from C. xanthocarpa seeds on the glucose tolerance curve are demonstrated in Figure 1. By 30, 60 and $180 \mathrm{~min}$ after starting the glucose tolerance test (which correspond to times 60, 90 and $210 \mathrm{~min}$, respectively), blood glucose concentration was significantly higher than at zero. A single oral administration of the extract (400 and $800 \mathrm{mg} / \mathrm{kg}$ ) caused a significant antihyperglycemic (-13.24\% and -6,85\%) effect after $60 \mathrm{~min}$ of treatment when compared to the respective hyperglycemic group ( $p<0.0001$ and 0.001 , respectively). Also, $400 \mathrm{mg} / \mathrm{kg}$ of extract significantly reduced the glycemia $(-9,30 \%)$ after $90 \mathrm{~min}(\mathrm{p}<0.0001)$. Additionally, $10 \mathrm{mg} / \mathrm{kg}$ glibenclamide, an insulin secretagogue, showed a typical hypoglycemic effect from 60 to $210 \mathrm{~min}$ after treatment, producing lower glucose levels compared to the hyperglycemic group $(\mathrm{p}<0.0001$ at all times). Finally, at

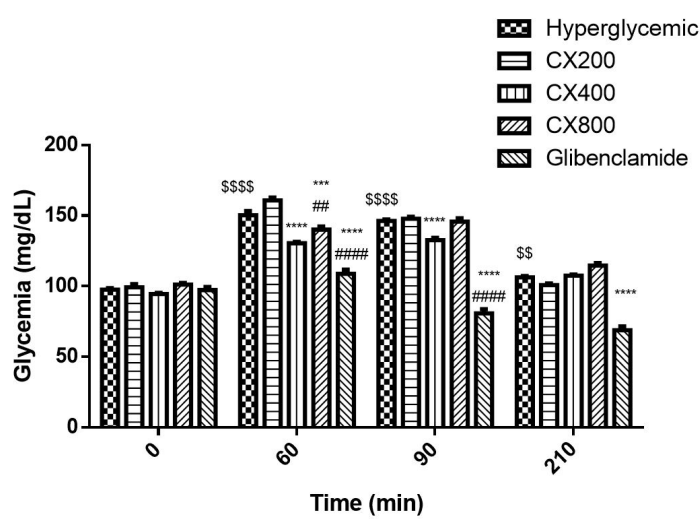

Figure 1. Effect of Campomanesia xanthocarpa extract (CX;200, 400 and $800 \mathrm{mg} / \mathrm{kg}$ ) and glibenclamide on oral glucose tolerance curve in hyperglycemic rats (that received glucose $4 \mathrm{~g} / \mathrm{Kg}$ by gavage). Values are expressed as mean \pm S.E.M. with $n=6$. Significant at $* * * \mathrm{p} \leq 0.001$ and $* * * * p \leq 0.0001$ compared with hyperglycemic control group at respective time; $\# \mathrm{p} \leq 0.01$ and $p \leq 0.0001$ compared with CX400 group at respective time and ${ }^{\$ S} \mathrm{p} \leq 0.01$ and ${ }^{\$ \$ \$ \$} p \leq 0.0001$ compared with hyperglycemic group at zero time (Two way ANOVA, Bonferroni post test).

all studied times no change was observed in insulin levels with the extract treatment (data not shown) suggesting that the effect of extract on glycemia is not due to increased pancreatic insulin secretion. Among the possible targets of action of natural products in glycemic control are the increased of glucose uptake by tissues, inhibition of intestinal glucose absorption, increased glycogen synthesis, inhibition of dipeptidyl peptidase-IV (DPP-IV), among others (Naveen and Baskaran, 2018). 
Our results are in accordance with the findings of the studies carried out with the leaves of $C$. xanthocarpa in diabetic rats (Vinagre et al., 2010) and in rats subject to a hypercaloric diet (Biavatti et al., 2004) that demonstrated the antihyperglycemic potential of this species. Apparently, the reduction in blood glucose was not as intense, however other pharmacological studies with medicinal plants with hypoglycemic properties consider $12 \%$ to $20 \%$ reduction in blood glucose levels a significant reduction (Sánchez-Salgado et al., 2007).

Several plants rich in terpenes, such as sesquiterpenes found in C. xanthocarpa have been shown an effect on blood glucose levels (Alam et al., 2018; Belhadj et al., 2018). Considering the presence of terpenoids in the extract, among them the caryophyllene that previously demonstrated anti-diabetic activity (Basha and Sankaranarayanan, 2014), the observed effect on glycemia may be due to the presence of these compounds. Furthermore, it is important to highlight that this is the first time that the antihyperglycemic potential of the seeds of C. xanthocarpa has been demonstrated evidencing the possibility of a better exploitation of the plant.

\subsection{Glycogen content after treatment with Campomanesia xanthocarpa extract}

Figure 2A shows that the muscle glycogen content was significantly increased $(+70.3 \%$ and $+57.44 \%) 210 \mathrm{~min}$ after the administration of 400 and $800 \mathrm{mg} / \mathrm{kg}$ of extract, respectively, compared with hyperglycemic rats $(\mathrm{p}<0.05)$. Moreover, the glycogen content in liver of rats treated with $400 \mathrm{mg} / \mathrm{kg}$ of extract enhanced $(+107.86 \%)$ when compared with hyperglycemic group $(p<0.05$; Figure $2 B)$.

Assessment of glycogen content is used as a marker for the evaluation of the antidiabetic activity of natural products (Kang et al., 2008). In mammals, glycogen accumulation is a physiological response to the increase in blood glucose concentration that occurs after a meal, with skeletal muscle and liver as the major storage sites. Glycogen metabolism is regulated by insulin/glucagon through activation and/or inhibition of several enzymes and proteins (Ferrer et al., 2003). The demonstration of the stimulatory effect of the C. xanthocarpa extract on glycogen content in the skeletal muscle and liver suggests an additional and expressive role in managing glucose in order to ameliorate the glucose postprandial state.

Our findings are in agreement with the study of Vinagre et al. (2010) that demonstrated the oral administration of decoction of $C$. xanthocarpa leaves restored the levels of glycogen in diabetic rats. Simillary Basha and Sankaranarayanan (2014) observed that carryophilene (sesquiterpene presentes in C.xanthocarpa) restored the levels of glycogen. Terpenoids and plant extracts with proven antihyperglycemic effect have been shown to influence glycogen deposition in different tissues as well as to interact with key enzymes of the glycolytic route (Sridhar et al. 2005; Henriques, 2017; Leonidas et al., 2017).
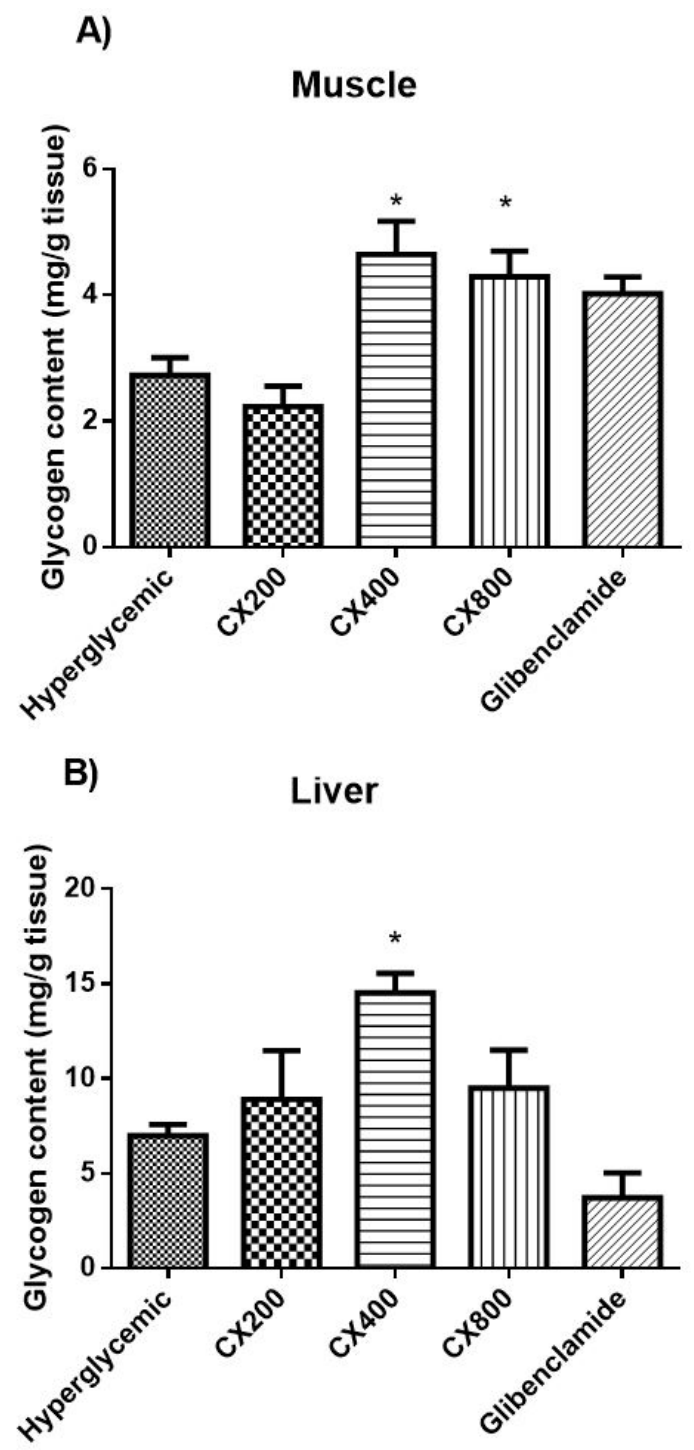

Figure 2. Effect of Campomanesia xanthocarpa extract (CX; 200, 400 and $800 \mathrm{mg} / \mathrm{kg}$ ) on muscle (A) and liver (B) glycogen content in hyperglycemic rats after $210 \mathrm{~min}$ of treatment. Values are expressed as mean \pm S.E.M.; $n=6$ in duplicate for each group. Statistically significant at $* p \leq 0.05$ compared with hyperglycemic control group (One-way ANOVA, Bonferroni post test).

\subsection{Inhibitory effect of Campomanesia xanthocarpa extract on disaccharidases activity}

The role of the C. xanthocarpa extract in disaccharidase assays are showed in Figure 3. A significant inhibitory effect on maltase $(-50.16,60.88$ and $57.50 \%$; $<<0.05$, $\mathrm{p}<0.01$ and $\mathrm{p}<0.01$, respectively, Figure $3 \mathrm{~A}$ ) and sucrase (79.59, 83,65 and 51.44; $\mathrm{p}<0.01, \mathrm{p}<0.01$ and $\mathrm{p}<0.05$, respectively, Figure $3 \mathrm{~B}$ ) activity was observed after $210 \mathrm{~min}$ of treatment with all doses $(200,400$ and $800 \mathrm{mg} / \mathrm{kg})$ of the extract in hyperglycemic rats. No significant changes were observed on lactase activity (Figure 3C). 
A)

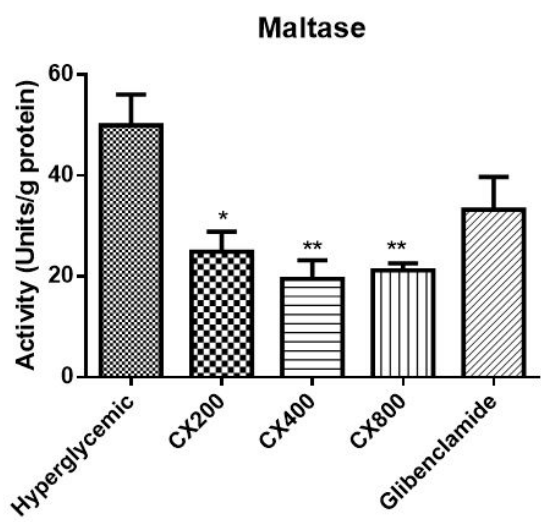

B)

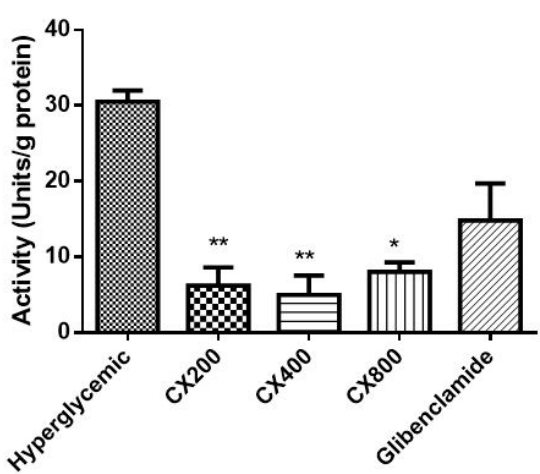

\section{C)}

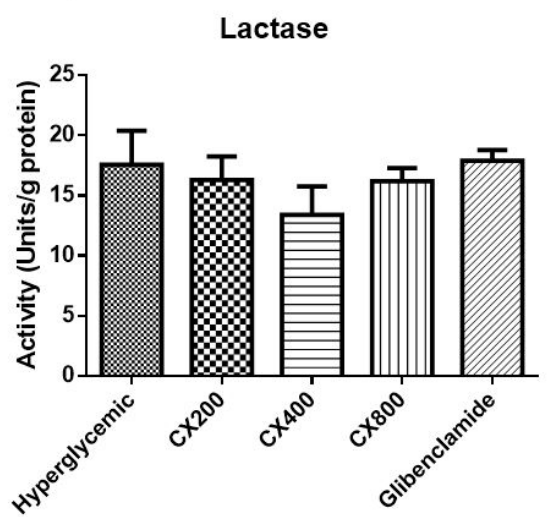

Figure 3. The acute effect of Campomanesia xanthocarpa extract (CX; 200, 400 and $800 \mathrm{mg} / \mathrm{kg}$ ) on A) Maltase, B) Sucrase and C) Lactase activity after 210 min of treatment. Values are expressed as mean \pm S.E.M.; $n=5$ in duplicate for each group. Statistically significant at $* p \leq 0.05$ and $* * \mathrm{p} \leq 0.01$ compared with hyperglycemic control group (One-way ANOVA, Bonferroni post test).

The intestine plays an important role in glucose homeostasis. Inhibition of the activity of the carbohydrate-hydrolyzing enzymes, such as $\alpha$-glucosidase, generates a delay in glucose absorption and is an important therapeutic approach in the control of postprandial glycemia (Melo and Carvalho, 2006). Some plants with properties similar to antidiabetic $\alpha$-glucosidase inhibitor drugs, such as acarbose, were identified (Kumar et al., 2011; Henriques, 2017). Additionally, studies have shown that sesquiterpenes, present in large quantities in the extract of C. xanthocarpa, have the ability to inhibit $\alpha$-glycosidases improving glucose metabolism (Alam et al., 2018) as well as other terpenes (Ding et al., 2018).

\subsection{Effect of Campomanesia xanthocarpa extract on lipid profile}

Figure 4 presents the lipid profile of hyperglycemic rats treated with C. xanthocarpa extract. The $400 \mathrm{mg} / \mathrm{kg}$ C. xanthocarpa-treated group presented significantly lower serum total cholesterol (TC) and LDL cholesterol concentrations than hyperglycemic group (Figure 4A and D, respectively). The reduction on TC levels was about $26 \%$, and the level of LDLwas reduced by around $49 \%$ in rats treated with $400 \mathrm{mg} / \mathrm{kg}$ of extract. All the doses of the extract were found to be ineffective in reducing both serum triglycerides, VLDL and HDL cholesterol.

Our results are in accordance with previous studies with humans demonstrating that oral administration of capsules of leaf from $C$. xanthocarpa reduced blood total cholesterol and LDL levels without changing the triglyceride, VLDL or HDL levels in hypercholesterolemic individuals (Klafke et al., 2010; Viecili et al., 2014). Also, Espindola et al. (2016) demonstrated that $C$. adamantium root aqueous extract displayed a reduction in serum levels of total cholesterol and triglycerides in rats. However, this hypocholesterolemic effect was not observed in rats treated with infusion (Biavatti et al., 2004) or decoction (Vinagre et al., 2010) of the leaves of $C$. xanthocarpa. These differences observed on $C$. xanthocarpa effect could be due to the different method of leaf preparation (trituration, infusion, decoction) which could be influencing in the amount and profile of bioactive compounds (Rodrigues et al., 2015). 
The presence of some phytochemicals like terpenes and flavonoids in C. xanthocarpa (Capeletto et al., 2016) could also be the cause of the decrease of total and LDL cholesterol since bioactive compounds act as reactive oxygen species scavengers (Klafke et al.,2010) or therefore, the possible mechanism involved in cholesterol reduction could be inhibition of HMG-CoA reductase, as demonstrated by Klafke et al. (2010). Baldissera et al. (2017) found that $\beta$-caryophyllene, a sesquiterpene presents in C. xanthocarpa extract seeds, has hypolipidemic effect via inhibition of the hepatic HMG-CoA reductase and Youssef et al. (2019) demonstrated that caryophillene improved glycemic parameters, dyslipidemia, and vascular oxidative stress in rats subject to diet-induced dyslipidemia.

It is estimated that $30-60 \%$ of patients with T2DM have dyslipidemia. Besides hyperglycemia, hyperlipidemia is another condition that presents a key role in the development of the micro- and macrovascular complications of diabete that may result in cardiovascular events like myocardial infarction and stroke (Feingold and Grunfeld, 2000). Thus,
A)

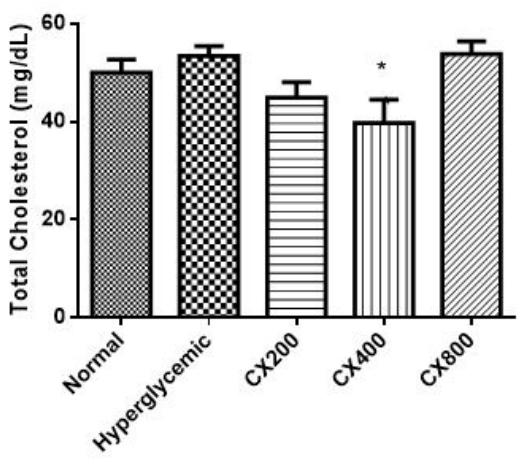

C)

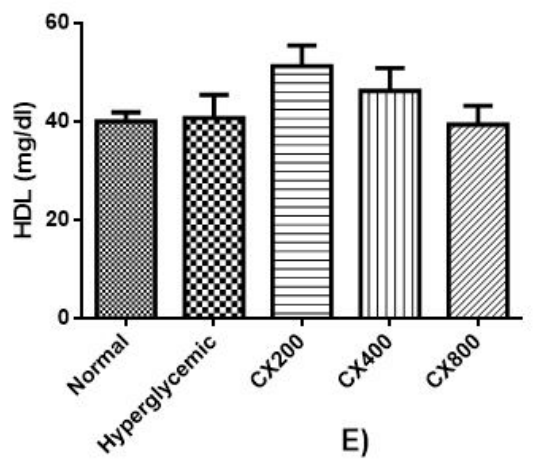

B)

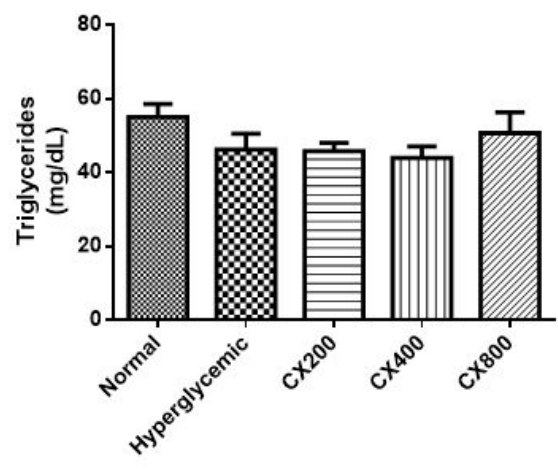

D)

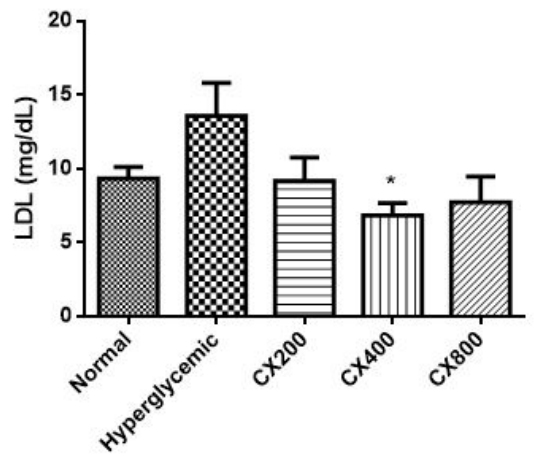

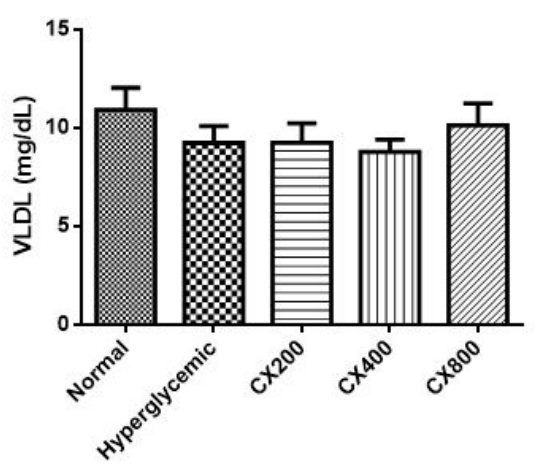

Figure 4. Lipid profile of rats treated with Campomanesia xanthocarpa extract (CX; 200, 400 and $800 \mathrm{mg} / \mathrm{kg}$ ). Total cholesterol (A), triglycerides (B), HDL (C), LDL (D) and VLDL (E) of hyperglycemic rats after 210 min of treatment. Values are expressed as mean \pm S.E.M.; $n=6$ in duplicate for each group. $* p \leq 0.05$ compared with hyperglycemic control group (One-way ANOVA, Bonferroni post test). 


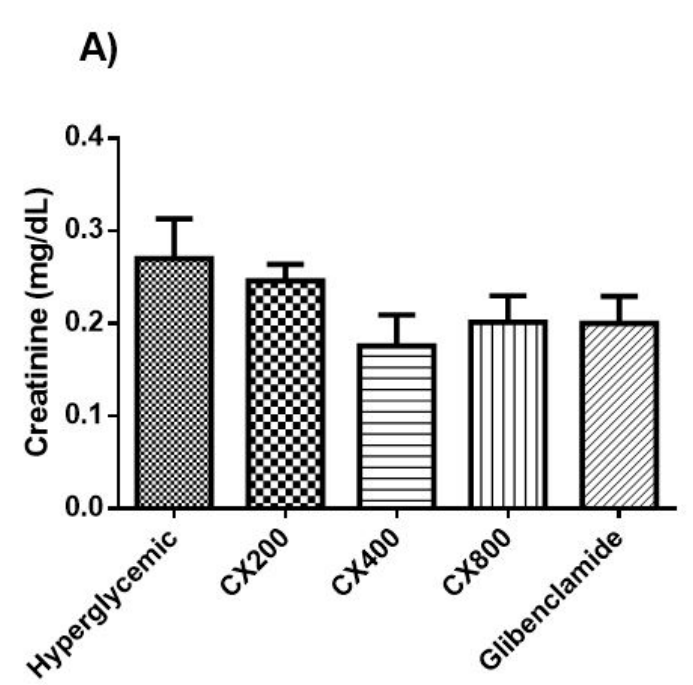

B)

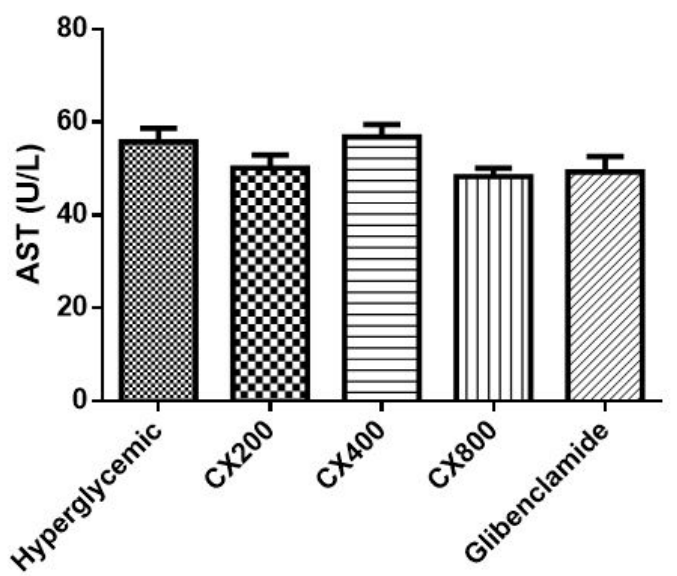

Figure 5. Effect of Campomanesia xanthocarpa extract (CX; 200, 400 and $800 \mathrm{mg} / \mathrm{kg}$ ) on serum AST (A) and creatinine (B) levels after $210 \mathrm{~min}$ of treatment. Values are expressed as mean \pm S.E.M.; $n=6$ in duplicate for each group.

T2DM patients with an increased risk for cardiovascular disease commonly use a combination therapy consisting of the anti-diabetic and a cholesterol-lowering drugs (van Stee et al., 2018). Therefore, the use of a single drug capable to control serum glucose and lipid levels is extremely advantageous.

\subsection{Effect of Campomansia xanthocarpa extract on assessment of hepatic and renal toxicity}

Figure 5 shows that there was no significant change on creatinine and AST levels in hyperglycemic rats treated with different doses of $C$. xanthocarpa, suggesting that acute administration does not cause damage to the liver and kidneys. Similarly, Viecili et al. (2014) demonstrated there was no significant change in the AST, ALT, urea and creatinine levels in hypercholesterolemic individuals after 90 days of treatment with $C$. xanthocarpa leaves. Additionally, da Silva et al. (2016b) demonstrated that animals exposed to C. xanthocarpa, did not exhibit clinical signs of acute toxicity for the administered doses.

\section{Conclusions}

In summary, our study showed for the first-time the in vivo beneficial role of $C$. xanthocarpa extract seeds, obtained by a green extraction technique, in glycemia and lipid profile on hyperglycemic rats. These data provide evidence to justify the use of $C$. xanthocarpa in the folk medicine to treat diabetes and hypercholesterolemia. Despite these findings, additional studies must be performed to define the mechanism of action and possible molecular target.

\section{Acknowledgements}

The authors gratefully acknowledge the financial supports by PIBIC/FAPE (010/Reitoria/2016) and Unochapecó.

\section{References}

ALAM, Md B., AN, H., RA, J.-S., LIM, J.-Y., LEE, S.-H., YOO, C.-Y., and LEE, S.-H., 2018. Gossypol from cottonseeds ameliorates glucose uptake by mimicking insulin signaling and improves glucose homeostasis in mice with streptozotocin-induced diabetes. Oxidative Medicine and Cellular Longevity, 2018, pp. 1-11.

ALICE, C.B., SIQUEIRA, N.C.S., MENTZ, L.A., BRASIL, G.A.A. and JOSÉ SILVA, K.F.D., 1995. Plantas medicinais de uso popular: atlas farmacognóstico. Canoas: Editora da Ulbra.

ALKHALIDY, H., WANG, Y. and LIU, D., 2018. Dietary Flavonoids in the Prevention of T2D: an Overview. Nutrients, vol. 10, no. 4, pp. 438. http://dx.doi.org/10.3390/nu10040438. PMid:29614722.

ASAKURA, K., KANEMASA, T., MINAGAWA, K., KAGAWA, K., YAGAMI, T., NAKAJIMA, M. and NINOMIYA, M., 2000. Alpha-eudesmol, a P/Q-type $\mathrm{Ca}(2+)$ channel blocker, inhibits neurogenic vasodilation and extravasation following electrical stimulation of trigeminal ganglion. Brain Research, vol. 873, no. 1, pp. 94-101. http://dx.doi.org/10.1016/S0006-8993(00)02527-0. PMid:10915814.

BALDISSERA, M.D., SOUZA, C.F., GRANDO, T.H., DOLESKI, P.H., BOLIGON, A.A., STEFANI, L.M. and MONTEIRO, S.G., 2017. Hypolipidemic effect of $\beta$ caryophyllene totreathyperlipidemic rats. Naunyn-Schmiedeberg's Archives of Pharmacology, vol. 390, no. 2, pp. 215-223. http://dx.doi.org/10.1007/s00210-0161326-3. PMid:27913825.

BASHA, R.H. and SANKARANARAYANAN, C., 2014. $\beta$-Caryophyllene, a natural sesquiterpene, modulates carbohydrate metabolism in streptozotocin-induced diabetic rats. Acta Histochemica, vol. 116, no. 8, pp. 1469-1479. http://dx.doi. org/10.1016/j.acthis.2014.10.001. PMid:25457874.

BELHADJ, S., HENTATI, O., HAMMAMI, M., BEN HADJ, A., BOUDAWARA, T., DAMMAK, M., ZOUARI, S. and EL FEKI, A., 2018. Metabolic impairments and tissue disorders in alloxan-induced diabetic rats are alleviated by Salvia officinalis L. essential oil. Biomedicine and Pharmacotherapy, vol. 108, pp. 985-995. http://dx.doi.org/10.1016/j.biopha.2018.09.108. PMid:30372910. 
BIAVATTI, M.W., FARIAS, C., CURTIUS, F., BRASIL, L.M., HORT, S., SCHUSTER, L., LEITE, S.N. and PRADO, S.R., 2004. Preliminary studies on Campomanesia xanthocarpa (Berg.) and Cuphea carthagenensis (Jacq.) J.F. Macbr. aqueous extract: weight control and biochemical parameters. Journal of Ethnopharmacology, vol. 93, no. 2-3, pp. 385-389. http://dx.doi. org/10.1016/j.jep.2004.04.015. PMid:15234782.

BOMFIM, D.S., FERRAZ, R.P., CARVALHO, N.C., SOARES, M.B., PINHEIRO, M.L., COSTA, E.V. and BEZERRA, D.P., 2013. Eudesmol isomers induce caspase-mediated apoptosis in human hepatocellular carcinoma HepG2 cells. Basic \& Clinical Pharmacology \& Toxicology, vol. 113, no. 5, pp. 300-306. http:// dx.doi.org/10.1111/bcpt.12097. PMid:23786320.

BRGLEZ MOJZER, E., KNEZ HRNČIČ, M., ŠKERGET, M., KNEZ, Ž. and BREN, U., 2016. Polyphenols: extraction methods, antioxidative action, bioavailability and anticarcinogenic effects. Molecules (Basel, Switzerland), vol. 21, no. 7, pp. 901. http:// dx.doi.org/10.3390/molecules21070901. PMid:27409600.

CAPELETTO, C., 2015. Obtenção de extratos bioativos da Campomanesiaxanthocarpa Berg a partir de diferentes métodos de extração e avaliação das atividades antimicrobiana e antioxidante. Chapecó: Universidade Comunitária da Região de Chapecó, 90 p. Dissertação de Mestrado Ciências Ambientais.

CAPELETTO, C., CONTERATO, G., SCAPINELlO, J., RODRIGUES, F.S., COPINI, M.S., KUHN, F., TRES, M.V., DAL MAGRO, J. and OLIVEIRA, J.V., 2016. Chemical composition, antioxidant and antimicrobial activity of guavirova (Campomanesia xanthocarpa Berg) seed extracts obtained by supercritical $\mathrm{CO}_{2}$ and compressed $n$-butane. The Journal of Supercritical Fluids, vol. 110, pp. 32-38. http://dx.doi.org/10.1016/j.supflu.2015.12.009.

CASTRO, A.J.G., CAZAROLLI, L.H., DALUZ, G., ALTENHOFEN, D., DA SILVA, H.B., DE CARVALHO, F.K., PIZZOLATTI, M.G. and SILVA, F.R.M.B., 2018. Fern-9(11)-ene-2 $\alpha, 3 \beta$-diol Action on Insulin Secretion under Hyperglycemic Conditions. Biochemistry, vol. 57, no. 26, pp. 3894-3902. http://dx.doi.org/10.1021/acs. biochem.8b00302. PMid:29792023.

CONSELHO NACIONAL DE CONTROLE DE EXPERIMENTAÇÃO ANIMAL - CONCEA, 2013. Diretriz Brasileira para o Cuidado e a Utilização de Animais para Fins Científicos e Didáticos $D B C A$. Brasília: CONCEA, pp. 1-50.

DAHLQVIST, A., 1984. Assay of intestinal disaccharidases. Scandinavian Journal of Clinical and Laboratory Investigation, vol. 44, no. 2, pp. 169-172. PMid:6719024.

DING, H., WU, X., PAN, J., HU, X., GONG, D. and ZHANG, G., 2018. New insights into the inhibition mechanism of betulinic acid on glucosidase. Journal of Agricultural and Food Chemistry, vol. 66, no. 27, pp. 7065-7075. http://dx.doi.org/10.1021/acs. jafc.8b02992. PMid:29902001.

ESPINDOLA, P.P.T., ROCHA, P.S., CAROLLO, C.A., SCHMITZ, W.O., PEREIRA, Z.V., VIEIRA, M.C., SANTOS, E.L. and SOUZA, K.P., 2016. Antioxidant and antihyperlipidemic effects of Campomanesia adamantium $\mathrm{O}$. Berg Root. Oxidative Medicine and Cellular Longevity, vol. 2016, pp. 1-8.

FEINGOLD, K.R. and GRUNFELD, C., 2000. Role of glucose and lipids in the cardiovascular disease of patients with diabetes. South Dartmouth, MA: Editors Endotext.

FERRER, J.C., FAVRE, C., GOMIS, R.R., FERNÁNDEZ-NOVELL, J.M., GARCÍA-ROCHA, M., DE LA IGLESIA, N., CID, E. and GUINOVART, J.J., 2003. Control of glycogen deposition. FEBS
Letters, vol. 546, no. 1, pp. 127-132. http://dx.doi.org/10.1016/ S0014-5793(03)00565-9. PMid:12829248.

FREDERICO, M.J.S., CASTRO, A.J.G., MASCARELLO, A., MENDES, C.P., KAPPEL, V.D., STUMPF, T.R., LEAL, P.C., NUNES, R.J., YUNES, R.A. and SILVA, F.R.M.B., 2012. Acylhydrazones contribute to serum glucose homeostasis through dual physiological targets. Current Topics in Medicinal Chemistry, vol. 12, no. 19, pp. 2049-2058. http://dx.doi.org/10.2174/156802612804910232. PMid:23167794.

GARCIA, M.C.F., SOARES, D.C., SANTANA, R.C., SARAIVA, E.M., SIANI, A.C., RAMOS, M.F.S., DANELLI, M.D.G.M., SOUTO-PADRON, T.C. and PINTO-DA-SILVA, L.H., 2018. The in vitro antileishmanial activity of essential oil from Aloysia gratissima and guaiol, its major sesquiterpene against Leishmania amazonensis. Parasitology, vol. 145, no. 9, pp. 1219-1227. http:// dx.doi.org/10.1017/S0031182017002335. PMid:29352826.

HENRIQUES, N.A.P., 2017. Investigação dos mecanismos de ação hipoglicemiantes do extrato de Bauhnia halophylla em fígado e músculo esquelético de camundongos diabéticos tipo 1 induzidos por estreptozotocina. Botucatu: Instituto de Biociências, Universidade Estadual Paulista "Júlio de Mesquita Filho". 96 p. Tese de Doutorado em Biologia Geral e Aplicada.

HUSSAIN, H., GREEN, I.R., ALI, I., KHAN, I.A., ALI, Z., ALSADI, A.M. and AHMED, I., 2017. Ursolic acid derivatives for pharmaceutical use: a patent review (2012-2016). Expert Opinion on Therapeutic Patents, vol. 27, no. 9, pp. 1061-1072. http:// dx.doi.org/10.1080/13543776.2017.1344219. PMid:28637397.

KANG, Y.J., JUNG, U.J., LEE, M.K., KIM, H.J., JEON, S.M., PARK, Y.B., CHUNG, H.G., BAEK, N.I., LEE, K.T., JEONG, T.S. and CHOI, M.S., 2008. Eupatilin, isolated from Artemisia princeps Pampanini, enhances hepatic glucose metabolism and pancreatic beta-cell function in type 2 diabetic mice. Diabetes Research and Clinical Practice, vol. 82, no. 1, pp. 25-32. http:// dx.doi.org/10.1016/j.diabres.2008.06.012. PMid:18703253.

KHAVANDI, M., DUARTE, F., GINSBERG, H.N. and REYESSOFFER, G., 2017. Treatment of Dyslipidemias to Prevent Cardiovascular Disease in Patients with Type 2 Diabetes. Current Cardiology Reports, vol. 19, no. 1, pp. 7. http://dx.doi.org/10.1007/ s11886-017-0818-1. PMid:28132397.

KLAFKE, J.Z., DA SILVA, M.A., PANIGAS, T.F., BELLI, K.C., DE OLIVEIRA, M.F., BARICHELLO, M.M., RIGO, F.K., ROSSATO, M.F., SOARES DOS SANTOS, A.R., PIZZOLATTI, M.G., FERREIRA, J. and VIECILI, P.R., 2010. Effects os Campomanesia xanthocarpa on biochemical, hematological and oxidative stress parameters in hypercholesterolemic patients. Journal of Ethnopharmacology, vol. 127, no. 2, pp. 299-305. http://dx.doi.org/10.1016/j.jep.2009.11.004. PMid:19914369.

KLAFKE, J.Z., SILVA, M.A., ROSSATO, M.F., TREVISAN, G., WALKER, C.I.B., LEAL, C.A.M., BORGES, D.O., SCHETINGER, M.R.C., MORESCO, R.N., DUARTE, M.M.M.F., SANTOS, A.R.S., VIECELLI, P.R.N. and FEREIRA, J., 2012. Antiplatelet, antithrombotic, and fibrinolytic activities of Campomanesia xanthocarpa. Evidence-Based Complementary and Alternative Medicine, vol. 2012, pp. 8. http://dx.doi.org/10.1155/2012/954748. PMid:21915188.

KNEZ, Ž., MARKOČIČ, E., LEITGEB, M., PRIMOŽIČ, M., KNEZ HRNČIC, M. and ŠKERGET, M., 2014. Industrial applications of supercritical fluids: a review. Energy, vol. 77, pp. 235-243. http://dx.doi.org/10.1016/j.energy.2014.07.044. 
KUMAR, S., NARWAL, S., KUMAR, V. and PRAKASH, O., 2011. $\alpha$-glucosidase inhibitors from plants: A natural approach to treat diabetes. Pharmacognosy Reviews, vol. 5, no. 9, pp. 19-29. http://dx.doi.org/10.4103/0973-7847.79096. PMid:22096315.

LEONIDAS, D.D., HAYES, J.M., KATO, A., SKAMNAKI, V.T., CHATZILEONTIADOU, D.S., KANTSADI, A.L., KYRIAKIS, E., CHETTER, B.A. and STRAVODIMOS, G.A., 2017. Phytogenic polyphenols as glycogen phosphorylase inhibitors: the potential of triterpenes and flavonoids for glycaemic control in Type 2 diabetes. Current Medicinal Chemistry, vol. 24, no. 4, pp. 384403. http://dx.doi.org/10.2174/0929867324666161118122534 PMid:27855623.

LORENZI, H., 2008. Árvores brasileiras: manual de identificação e cultivo de plantas arbóres nativas do Brasil. Nova Odessa: Editora Plantarum.

MARKMAN, B., BACCHI, E. and KATO, E., 2004. Antiulcerogenic effects of Campomanesia xanthocarpa. Journal of Ethnopharmacology, vol. 94, no. 1, pp. 55-57. http://dx.doi. org/10.1016/j.jep.2004.04.025. PMid:15261963.

MELO, E.B. and CARVALHO, I., 2006. $\alpha$ and $\beta$-glucosidases as molecular targets for drug development. Quimica Nova, vol. 29 , no. 4 , pp. $840-843$.

NAVEEN, J. and BASKARAN, V., 2018. Antidiabetic plantderived nutraceuticals: a critical review. European Journal of Nutrition, vol. 57, no. 4, pp. 1275-1299. http://dx.doi.org/10.1007/ s00394-017-1552-6. PMid:29022103.

NICOLAU, J., DE SOUZA, D.N. and CARRILHO, M., 2009. Increased glycated calmodulin in the submandibular salivary glands of streptozotocin-induced diabetic rats. Cell Biochemistry and Function, vol. 27, no. 4, pp. 193-198. http://dx.doi.org/10.1002/ cbf.1555. PMid:19367566.

OTERO, J.S., HIRSCH, G.E., KLAFKE, J.Z., PORTO, F.G., ALMEIDA, A.S., NASCIMENTO, S., SCHMIDT, A., SILVA, B., PEREIRA, R.L.D., JASKULSKI, M., PARISI, M.M., SANTOS GUARDA, N., MORESCO, R.N., AITA, C.A.M. and VIECILI, P.R.N., 2017. Inhibitory effect of Campomanesia xanthocarpa in platelet aggregation: comparison and synergism with acetylsalicylic acid. Thrombosis Research, vol. 154, pp. 42-49. http://dx.doi. org/10.1016/j.thromres.2017.03.020. PMid:28410506.

PANT, A., SAIKIA, S.K., SHUKLA, V., ASTHANA, J., AKHOON, B.A. and PANDEY, R., 2014. Beta-caryophyllene modulates expression of stress response genes and mediates longevity in Caenorhabditiselegans. Experimental Gerontology, vol. 57, pp. 81-95. http://dx.doi.org/10.1016/j.exger.2014.05.007. PMid:24835194.

PAULA, J.T., AGUIAR, A.C., SOUSA, I.M.O., MAGALHÃES, P.M., FOGLIO, M.A. and CABRAL, F.A., 2016. Scale-up study of supercritical fluid extraction process for Baccharis dracunculifolia. The Journal of Supercritical Fluids, vol. 107, pp. 219-225. http:// dx.doi.org/10.1016/j.supflu.2015.09.013.

PEREIRA, D.F., KAPPEL, V.D., CAZAROLLI, L.H., BOLIGON, A.A., ATHAYDE, M.L., GUESSER, S.M., SILVA, E.L. and SILVA, F.R., 2012. Influence of the traditional Brazilian drink Ilex paraguariensis tea on glucose homeostasis. Phytomedicine: International Journal of Phytotherapy and Phytopharmacology, vol. 19, no. 10, pp. 868-877. http://dx.doi.org/10.1016/j. phymed.2012.05.008. PMid:22795927.

PETERSON, G.L., 1979. Review of the Folin phenol protein quantitation method of Lowry, Rosebrough, Farr and Randall.
Analytical Biochemistry, vol. 100, no. 2, pp. 201-220. http://dx.doi. org/10.1016/0003-2697(79)90222-7. PMid:393128.

RODRIGUES, V.C., SILVA, M.V., SANTOS, A.R., ZIELINSKI, A.A.F. and HAMINIUK, C.W.I., 2015. Evaluation of hot and cold extraction of bioactive compounds in teas. International Journal of Food Science \& Technology, vol. 50, no. 9, pp. 2038-2045. http://dx.doi.org/10.1111/ijfs.12858.

RODRÍGUEZ-PÉREZ, C., MENDIOLA, J.A., QUIRANTESPINÉ, R., IBÁÑEZ, E. and SEGURA-CARRETERO, A., 2016. Green downstream processing using supercritical carbon dioxide, $\mathrm{CO} 2$-expanded ethanol and pressurized hot water extractions for recovering bioactive compounds from Moringa oleifera leaves. The Journal of Supercritical Fluids, vol. 116, pp. 90-100. http:// dx.doi.org/10.1016/j.supflu.2016.05.009.

RUTTARATTANAMONGKOL, K., SIEBENHANDL-EHN, S., SCHREINER, M. and PETRASCH, A.M., 2014. Pilotscale supercritical carbon dioxide extraction, physico-chemical properties and profile characterization of Moringa oleifera seed oil in comparison with conventional extraction methods. Industrial Crops and Products, vol. 58, pp. 68-77. http://dx.doi. org/10.1016/j.indcrop.2014.03.020.

SÁNCHEZ-SALGADO, J.C., ORTIZ-ANDRADE, R.R., AGUIRRECRESPO, F., VERGARA-GALICIA, J., LEONRIVERA, I., MONTES, S., VILLALOBOS-MOLINA, R. and ESTRADASOTO, S., 2007. Hypoglycemic, vasorelaxant and hepatoprotective effects of Cochlospermum vitifolium (Willd.) Sprengel: a potential agent for the treatment of metabolic syndrome. Journal of Ethnopharmacology, vol. 109, no. 3, pp. 400-405. http://dx.doi. org/10.1016/j.jep.2006.08.008. PMid:16978815.

SANT'ANNA, L.S., MERLUGO, L., EHLE, C.S., LIMBERGER, J., FERNANDES, M.B., SANTOS, M.C., MENDEZ, A.S.L., PAULA, F.R. and MOREIRA, C.M., 2017. Chemical composition and hypotensive effect of Campomanesia xanthocarpa. EvidenceBased Complementary and Alternative Medicine, vol. 2017, pp. 1591762. http://dx.doi.org/10.1155/2017/1591762.

SCAPINELLO, J., AGUIAR, G.P.S., DAL MAGRO, C., CAPELEZZO, A.P., NIERO, R., DAL MAGRO, J., OLIVEIRA, D. and OLIVEIRA, J.V., 2018. Extraction of bioactive compounds from Philodendron bipinnatifidum Schott ex Endl and encapsulation in PHBV by SEDS technique. Industrial Crops and Products, vol. 125, pp. 65-71. http://dx.doi.org/10.1016/j.indcrop.2018.08.079.

SHI, L.K., ZHENG, L., LIU, R.J., CHANG, M., JIN, Q.Z. and WANG, X.G., 2018. Chemical characterization, oxidative stability, and in vitro antioxidant capacity of sesame oils extracted by supercritical and subcritical techniques and conventional methods: a comparative study using chemometrics. European Journal of Lipid Science and Technology, vol. 120, no. 2, pp. 1700326. http://dx.doi.org/10.1002/ejlt.201700326.

SILVA, É.R., SALMAZZO, G.R., ARRIGO, J.S., OLIVEIRA, R.J., KASSUYA, C.A. and CARDOSO, C.A., 2016b. Anti-inflammatory evaluation and toxicological analysis of Campomanesia xanthocarpa Berg. Inflammation, vol. 39, no. 4, pp. 1462-1468. http://dx.doi. org/10.1007/s10753-016-0378-3. PMid:27271512.

SILVA, R.P.F.F., ROCHA-SANTOS, T.A.P. and DUARTE, A.C., 2016a. Supercritical fluid extraction of bioactive compounds. Trends in Analytical Chemistry, vol. 76, pp. 40-51. http://dx.doi. org/10.1016/j.trac.2015.11.013

SOUZA-MOREIRA, T.M., SALVAGNINI, L.E., SANTOS, E., SILVA, V.Y.A., MOREIRA, R., SALGADO, H.R.N. and PIETRO, R., 2011. Antidiarrheal activity of Campomanesia xanthocarpa 
fruit. Journal of Medicinal Food, vol. 14, no. 5, pp. 528-531. http://dx.doi.org/10.1089/jmf.2009.0278. PMid:21480796.

SRIDHAR, S.B., SHEETAL, U.D., PAI, M.R. and SHASTRI, M.S., 2005. Preclinical evaluation of the antidiabetic effect of Eugenia jambolana seed powder in streptozotocin-diabetic rats. Brazilian Journal of Medical and Biological Research, vol. 38, no. 3, pp. 463-468. http://dx.doi.org/10.1590/S0100-879X2005000300018. PMid:15761627.

TANGVARASITTICHAI, S., 2015. Oxidative stress, insulin resistance, dyslipidemia and type 2 diabetes mellitus. World Journal of Diabetes, vol. 6, no. 3, pp. 456-480. http://dx.doi. org/10.4239/wjd.v6.i3.456. PMid:25897356.

VAN STEE, M.F., DE GRAAF, A.A. and GROEN, A.K., 2018. Actions of metformin and statins on lipid and glucose metabolism and possible benefit of combination therapy. Cardiovascular Diabetology, vol. 17, no. 1, pp. 17. http://dx.doi.org/10.1186/ s12933-018-0738-4. PMid:29960584.

VIECILI, P.R.N., BORGES, D.O., KIRSTEN, K., MALHEIROS, J., VIECILI, E., MELO, R.D., TREVISAN, G., SILVA, M.A., BOCHI, G.V., MORESCO, R.N. and KLAFKE, J.Z., 2014. Effects of Campomanesia xanthocarpa on inflammatory processes, oxidative stress, endothelial dysfunction and lipid biomarkers in hypercholesterolemic individuals. Atherosclerosis, vol. 234, no. 1, pp. 85-92. http://dx.doi.org/10.1016/j.atherosclerosis.2014.02.010. PMid:24632042.

VINAGRE, A.P.S., RONNAU, A.D.S.R.O., PEREIRA, S.F., SILVEIRA, L.U., WIILLAND, E.F. and SUYENAGA, E.S., 2010. Anti-diabetic effects of Campomanesia xanthocarpa (Berg) leaf decoction. Brazilian Journal of Pharmaceutical Sciences, vol. 46, no. 2, pp. 169-177. http://dx.doi.org/10.1590/S198482502010000200002 .

WORLD HEALTH ORGANIZATION - WHO, 2002. Traditional Medicine Strategy 2002-2005. Geneva: WHO. Available from: https://www.who.int/medicines/publications/traditionalpolicy/en/

WORLD HEALTH ORGANIZATION - WHO, 2018 [viewed 13 August 2019]. Diabetes [online]. Geneva: WHO. Available from: http://www.who.int/mediacentre/factsheets/fs312/en/\#

YANG, Q., WU, J., LUO, Y., HUANG, N., ZHEN, N., ZHOU, Y., SUN, F., LI, Z., PAN, Q. and LI, Y., 2016. (-)-Guaiol regulates RAD51 stability via autophagy to induce cell apoptosis in non-small cell lung cancer. Oncotarget, vol. 7, no. 38, pp. 62585-62597. http://dx.doi.org/10.18632/oncotarget.11540. PMid:27566579.

YOUSSEF, D.A., EL-FAYOUMI, H.M. and MAHMOUD, M.F., 2019. Beta-caryophyllene protects against diet-induced dyslipidemia and vascular inflammation in rats: involvement of CB2 and PPAR- $\gamma$ receptors. Chemico-Biological Interactions, vol. 297, pp. 16-24. http://dx.doi.org/10.1016/j.cbi.2018.10.010. PMid:30343038.

ZANATTA, L., ROSSO, A., FOLADOR, P., FIGUEIREDO, M.S., PIZZOLATTI, M.G., LEITE, L.D. and SILVA, F.R., 2008. Insulinomimetic effect of kaempferol 3-neohesperidoside on the rat soleus muscle. Journal of Natural Products, vol. 71, no. 4, pp. 532-535. http://dx.doi.org/10.1021/np070358+. PMid:18303854.

ZHAO, G., LI, X., CHEN, W., XI, Z. and SUN, L., 2012. Three new sesquiterpenes from Tithonia diversifolia and their antihyperglycemic activity. Fitoterapia, vol. 83, no. 8, pp. 1590-1597. http://dx.doi.org/10.1016/j.fitote.2012.09.007. PMid:22986291. 